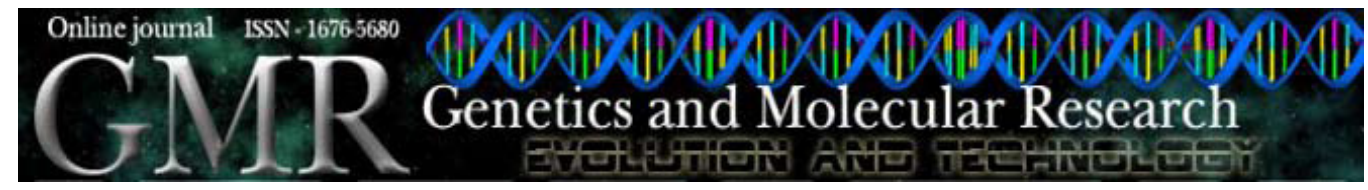

\title{
Genetic diversity analysis with RAPD linked to sex identification in the sugar cane borer Diatraea saccharalis
}

\author{
C. Heideman, R.E.F. Munhoz, J.R. Pattaro Júnior and M.A. Fernandez \\ Departamento de Biologia Celular e Genética, \\ Universidade Estadual de Maringá, Maringá, PR, Brasil \\ Corresponding author: M.A. Fernandez \\ E-mail: aparecidafernandez@gmail.com
}

Genet. Mol. Res. 9 (4): 2343-2348 (2010)

Received August 13, 2010

Accepted September 23, 2010

Published November 30, 2010

DOI 10.4238/vol9-4gmr974

\begin{abstract}
Diatraea saccharalis is an insect that causes considerable losses in the sugar cane crop. Our aim was to contribute to the knowledge of the biology of D. saccharalis, with the report of DNA fragments involved in the differentiation between the male and female of this species using the RAPD sex molecular marker GyakuU-13, which is specific for the $\mathrm{W}$ chromosome of Bombyx mori. Another point evaluated in this study was the genetic diversity of a $D$. saccharalis population maintained by inbreeding in a laboratory culture. The profile of sex-specific fragments was analyzed, and the genetic variability of this population was estimated. An analysis of the molecular markers showed only one fragment, of approximately $700 \mathrm{bp}$, that could be considered as a female sex marker in D. saccharalis.
\end{abstract}

Key words: Diatraea saccharalis; RAPD; Sex-specific marker; Genetic diversity 


\section{INTRODUCTION}

In Brazil, the sugar cane borer, Diatraea saccharalis (Fabricius, 1794), is a pest that causes considerable damage to the sugar-ethanol agribusiness. The damage caused by this insect results in the formation of galleries in the stem, leaving the plant vulnerable to the entry of fungi, which are responsible for the inversion of sucrose (Botelho, 1992). Biologically, this pest has been controlled since the creation of the massive wasp Cotesia flavipes (Hymenoptera, Braconidae) in specialized laboratories, since there is as yet no effective insecticide for its control (Alleyne et al., 2001).

D. saccharalis studies in the literature are about their rearing, population dynamics, parasitoid-host relationships, and some basic aspects of morphology, physiology and molecular biology (Conte, 1994; Dossi and Conte, 2002; Ruvolo-Takasusuki et al., 2002; Beserra and Parra, 2004; Victoriano and Gregorio, 2004; Bravo et al., 2008). Recently, our research group published the first putative antimicrobial peptide from $D$. saccharalis against bacterial infection (Silva et al., 2010). However, whether it is possible to determine molecular markers linked to sex determination in this insect is unknown. The lack of knowledge hampers the implementation of techniques for their biological control, since there is need for basic knowledge of insect biology to conduct evaluations of the interactions between the parasite and its host.

In Lepidoptera, the identification of individual chromosomes based on the size and banding patterns is difficult because they have a large number of chromosomes, which have small and apparent similar sizes (Mandrioli et al., 2003). In this insect order, the females have heterogametic sex chromosomes, represented as WZ, and the male, ZZ. Preliminary cytogenetic studies in $D$. saccharalis indicate the presence of numerous tiny chromosomes with similar morphology (Heideman C, personal communication).

Due to the difficulty in identifying sex in early larval stages and studying the karyotype, several recent studies have tried to correlate DNA markers with sex identification in insects such as Ostrinia nubilalis Hübner (Coates and Hellmich, 2003) and Cydia pomonella (Fuková et al., 2007). The identification of molecular markers for the sex chromosome of Bombyx mori (Abe et al., 1998, 2005) enables the recognition of the genetic sex of an embryo or larva; such marker would be attractive in the case of $D$. saccharalis. In this study, we determined the feasibility of using the molecular marker GyakuU-13, involved in sex identification in the silkworm silk, in sugar cane borer individuals. Another point evaluated in this study was the genetic diversity of a $D$. saccharalis population maintained by inbreeding in a laboratory culture.

\section{MATERIAL AND METHODS}

Individuals of $D$. saccharalis were reared under controlled environmental conditions (12-h light/dark cycle, $25 \pm 1{ }^{\circ} \mathrm{C}, 70 \%$ relative humidity) with artificial diet (Hensley and Hammond, 1968).

The genomic DNA of moths, 14 individuals of each sex, was extracted as described by Monesi et al. (1998), with modifications. Briefly, the moths were macerated in liquid nitrogen, followed by the addition of $350 \mu \mathrm{L}$ homogenization buffer $(10 \mathrm{mM}$ Tris- $\mathrm{HCl}, \mathrm{pH} 7.5,60 \mathrm{mM}$ $\mathrm{NaCl}, 10 \mathrm{mM}$ EDTA, pH 8.0, 5\% sucrose, $0.15 \mathrm{mM}$ spermidine, $0.15 \mathrm{mM}$ spermine). Proteins 
were removed by the addition of an equal volume of proteinase $\mathrm{K}$ buffer $(200 \mathrm{mM}$ Tris- $\mathrm{HCl}$, $\mathrm{pH} 9.0,30 \mathrm{mM}$ EDTA, $\mathrm{pH} 8.0,2 \% \mathrm{SDS}$ ) and $100 \mu \mathrm{g} / \mathrm{mL}$ proteinase $\mathrm{K}$, and incubation for $1 \mathrm{~h}$ at $60^{\circ} \mathrm{C}$. DNA was purified by extraction and precipitation as described elsewhere (Sambrook and Russel, 2001) and stored at $-20^{\circ} \mathrm{C}$.

The primer GyakuU-13 (5' CCTTGGTCGG 3') was used for amplification reactions from genomic DNA of $D$. saccharalis, as described by Abe et al. (2005). After amplification, the product was subjected to electrophoresis on a $1.5 \%$ agarose gel for $1 \mathrm{~h}$ at $100 \mathrm{~V}$ and a $6 \%$ polyacrylamide gel for $8 \mathrm{~h}$ at $110 \mathrm{~V}$.

For analysis of the genetic diversity of the population, a matrix was built with the binary data of presence and absence of bands of identical molecular size (same fragment), with identification of each individual. This similarity matrix encoding " 1 " as the presence of the band in the gel and "0" as its absence was used to determine genetic distances between all possible pairs of individuals. The genetic variability between individuals was estimated using the method of Nei's unbiased genetic distance (1978). The analyses were made in the PopGene 1.32 statistical program (Yeh and Boyle, 1997), considering the parameters for dominant markers in diploids. In order to plot the pattern of genetic divergence, a dendrogram based on Nei's genetic distance (1978) was obtained, using the UPGMA clustering algorithm (unweighted pair-group method using arithmetic average).

\section{RESULTS AND DISCUSSION}

Figure 1 shows the molecular marker GyakuU-13, used to detect a sex-specific marker in D. saccharalis DNA and the positive control with the amplification of B. mori female and male samples. The amplified samples generated several fragments in D. saccharalis, and it was evident that the presence of a fragment of approximately $700 \mathrm{bp}$ was unique for the DNA samples from female moths. The size of the amplicon in $D$. saccharalis differs from that obtained by Abe et al. (2005), described as $600 \mathrm{bp}$ in strains of $B$. mori using the same primer. This fact could be explained because this marker sequence is associated with repetitions in the genome, and it is not surprising that the result is different with $D$. saccharalis. These data demonstrate that the primer GyakuU-13 can be used as a sex-specific molecular marker in $D$. saccharalis.

The primer GyakuU-13 produced 39 fragments of molecular size between 220$3054 \mathrm{bp}$ in the experiments. In the total of the analyzed loci, it was observed that all were polymorphic $(100 \%)$. The high number of bands generated by amplification with primer GyakuU-13 shows the possible variability among the individuals and the ability to estimate its probable genetic distance. The results are shown in the dendrogram depicted in Figure 2. It is evident that the individuals were grouped together according to sex. The male is subdivided into two subgroups and female into four subgroups.

This preliminary study will lead to future studies to develop research strategies and the construction of a molecular genetic marker to identify genes or DNA segments related to sex determination in $D$. saccharalis.

In summary, this study showed that there is binding of a fragment profile with, at least, one fragment related to sexual identity in Diatraea saccharalis, and that this population has significant reserves of genetic variability. 


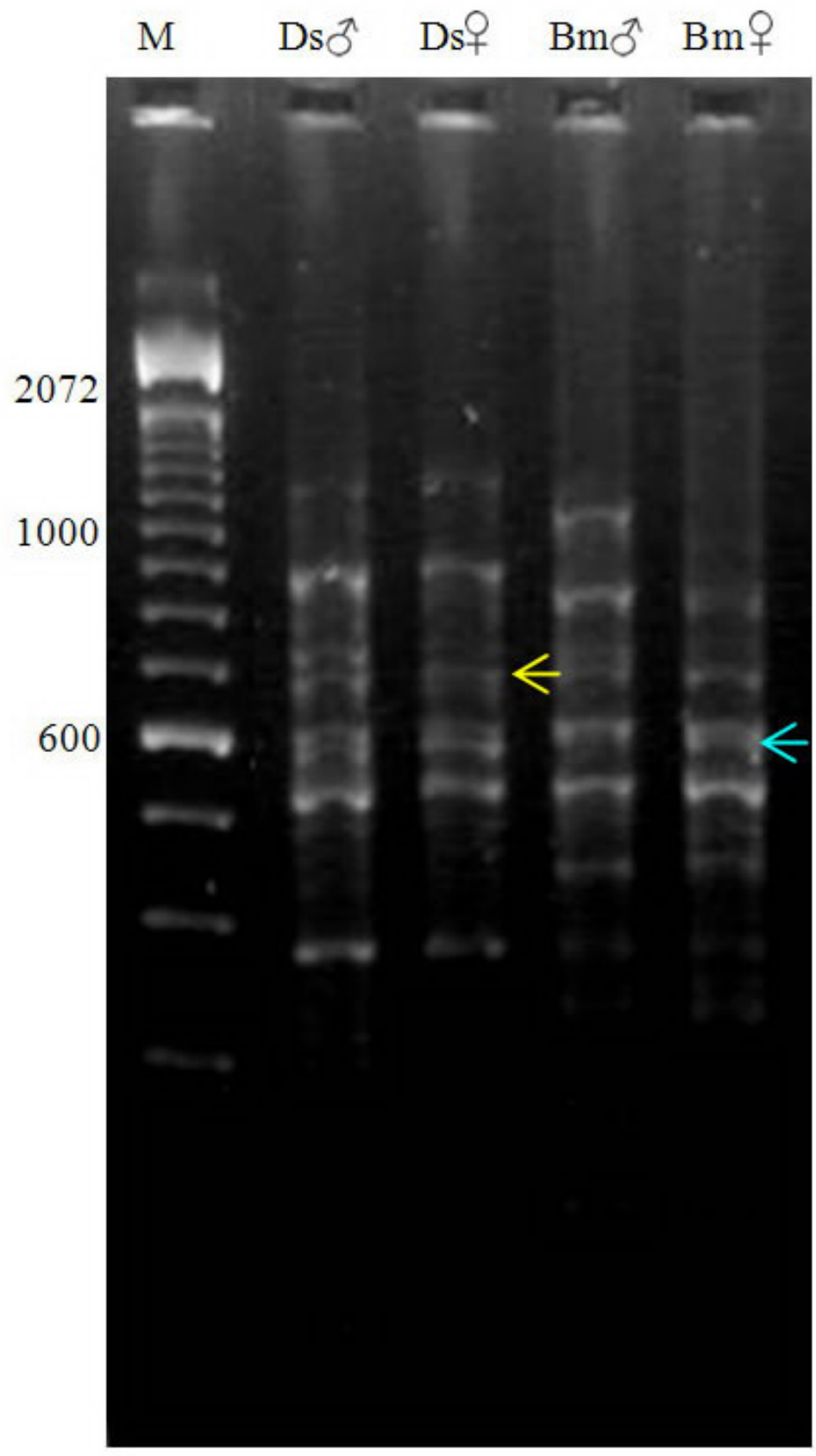

Figure 1. Diatraea saccharalis sex molecular marker. The amplicon of $\sim 700$ bp (yellow arrow) was detected only in D. saccharalis (Ds) females, using the RAPD GyakuU-13 primer. The positive control was carried out with Bombyx mori (Bm) DNA, where a fragment of $\sim 600$ bp (blue arrow) was detected only in female DNA ( $6 \%$ polyacrylamide gel). $\mathrm{M}=100$-bp molecular weight marker (Invitrogen). 


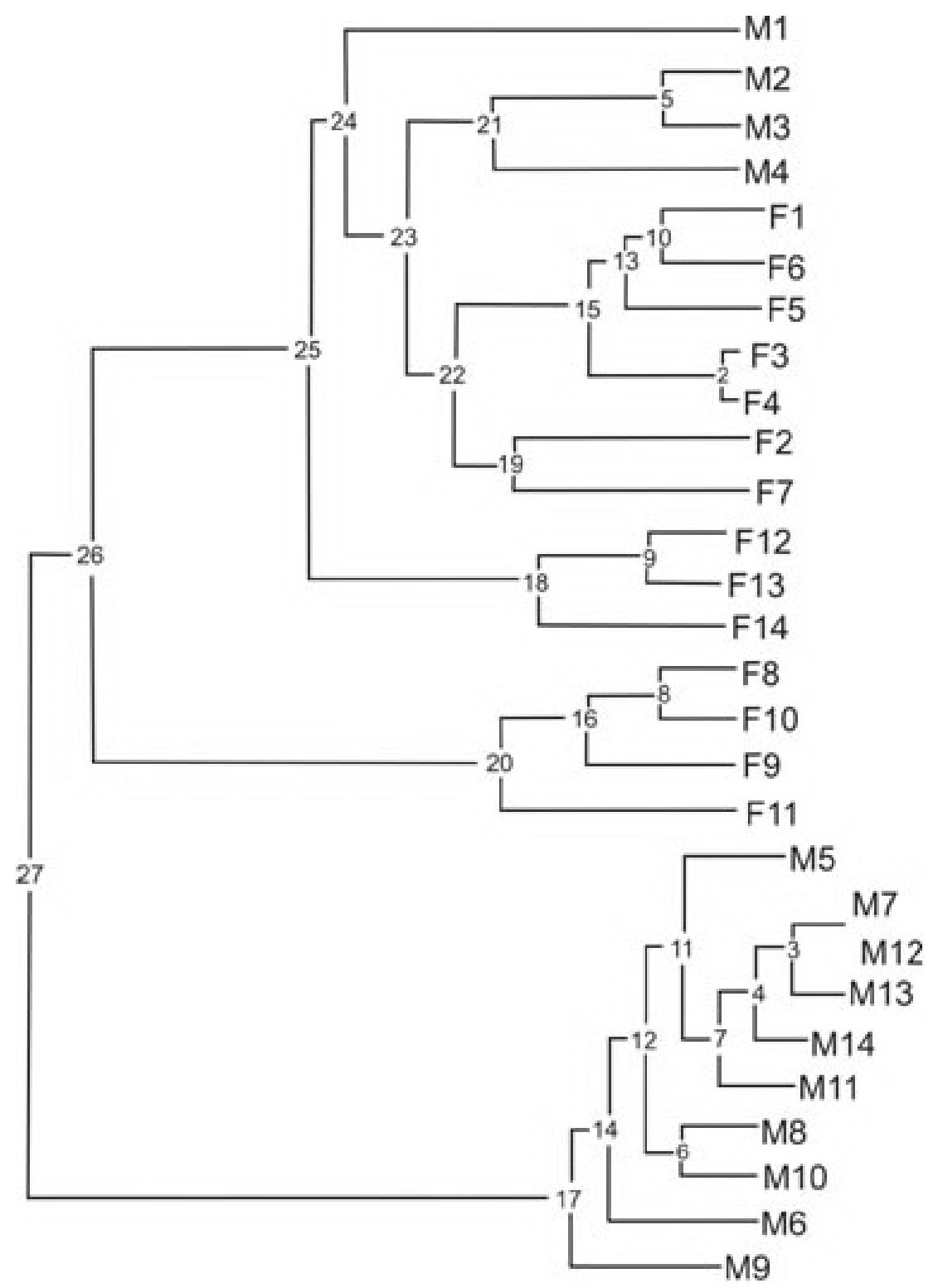

Figure 2. Cluster analysis of the 14 individuals of each sex of Diatraea saccharalis using the method of Nei's unbiased genetic distance (1978) and grouping using UPGMA (unweighted pair group method).

\section{ACKNOWLEDGMENTS}

We thank Valmir Peron and Marli Licero Schuete Silva for dedicated technical assistance and Universidade Estadual de Maringá for the use of its facilities (COMCAP laboratories). 


\section{REFERENCES}

Abe H, Kanehara M, Terada T, Ohbayashi F, et al. (1998). Identification of novel random amplified polymorphic DNAs (RAPDs) on the $\mathrm{W}$ chromosome of the domesticated silkworm, Bombyx mori, and the wild silkworm, B. mandarina, and their retrotransposable element-related nucleotide sequences. Genes Genet. Syst. 73: 243-254.

Abe H, Seki M, Ohbayashi F, Tanaka N, et al. (2005). Partial deletions of the W chromosome due to reciprocal translocation in the silkworm Bombyx mori. Insect Mol. Biol. 14: 339-352.

Alleyne M, Wiedenmann RN and Diaz RR (2001). Quantification and development of teratocytes in novel-association host-parasitoid combinations. J. Insect Physiol. 47: 1419-1427.

Beserra EB and Parra JRP (2004). Biologia e parasitismo de Trichogramma atopovirilia Oatman \& Platner e Trichogramma pretiosum Riley (Hymenoptera, Trichogrammatidae) em ovos de Spodoptera frugiperda (J.E. Smith) (Lepidoptera, Noctuidae). Rev. Bras. Entomol. 48: 119-126.

Botelho PSM (1992). Quinze anos de controle biológico da Diatraea saccharalis utilizando parasitóides. Pesqui. Agrop. Bras. 27: 255-262.

Bravo JP, Silva JL, Munhoz RE and Fernandez MA (2008). DNA barcode information for the sugar cane moth borer Diatraea saccharalis. Genet. Mol. Res. 7: 741-748.

Coates BS and Hellmich RL (2003). Two sex-chromosome-linked microsatellite loci show geographic variance among North American Ostrinia nubilalis. J. Insect Sci. 3: 29.

Conte H (1994). Morfologia do Corpo Gorduroso em Larva de Diatraea saccharalis (Lepidoptera: Pyralidae) não Parasitadas e Parasitadas pelo Cotesia flavipes (Hymenoptera: Braconidae). Instituto de Biociências, Universidade Estadual Paulista, Rio Claro, 160.

Dossi FCA and Conte H (2002). Embriologia de D. saccharalis (Lepidoptera: Pyralidae). Arq. Apadec 6: 36.

Fuková I, Traut W, Vitkova M, Nguyen P, et al. (2007). Probing the W chromosome of the codling moth, Cydia pomonella, with sequences from microdissected sex chromatin. Chromosoma 116: 135-145.

Hensley SD and Hammond AM (1968). Laboratory techniques for rearing the sugarcane borer on an artificial diet. J. Econ. Entomol. 61: 1742-1743.

Mandrioli M, Manicardi GC and Marec F (2003). Cytogenetic and molecular characterization of the MBSAT1 satellite DNA in holokinetic chromosomes of the cabbage moth, Mamestra brassicae (Lepidoptera). Chromosome Res. 11: 51-56.

Monesi N, Jacobs-Lorena M and Paco-Larson ML (1998). The DNA puff gene BhC4-1 of Bradysia hygida is specifically transcribed in early prepupal salivary glands of Drosophila melanogaster. Chromosoma 107: 559-569.

Nei M (1978). Estimation of average heterozygosity and genetic distance from a small number of individuals. Genetics 89: $583-590$

Ruvolo-Takasusuki MCC, Machado MFPS and Conte H (2002). Esterase-3 polymorphism in the sugarcane borer Diatraea saccharalis (Lepidoptera, Pyralidae). Genet. Mol. Biol. 25: 61-64.

Sambrook J and Russel DW (2001). Molecular Cloning: A Laboratory Manual. 3rd edn. Cold Spring Harbor Laboratory Press, Cold Spring Harbor, New York.

Silva JL, Barbosa JF, Bravo JP, Souza EM, et al. (2010). Induction of a gloverin-like antimicrobial polypeptide in the sugarcane borer Diatraea saccharalis challenged by septic injury. Braz. J. Med. Biol. Res. 43: 431-436.

Victoriano E and Gregorio EA (2004). Ultrastructure of the Lyonet's glands in larvae of Diatraea saccharalis Fabricius (Lepidoptera: Pyralidae). Biocell 28: 165-169.

Yeh FC and Boyle TJB (1997). Population genetic analysis of co-dominant and dominant markers and quantitative traits. Belg. J. Bot. 129: 157. 